\title{
I!:
}

\section{RESTAURAÇÃO FLORESTAL DE UMA ÁREA DE VEGETAÇÃO RIPÁRIA NO SÍTIO PAMPULHA, MUNICÍPIO DE LINHARES, ES}

\author{
FOREST RESTORATION OF A RIPARY VEGETATION AREA IN THE \\ PAMPULHA SITE, CITY OF LINHARES-ES
}

\author{
Letícia Boina $\mathrm{Cau}^{1 *}$ \\ ${ }^{1}$ Faculdade Pitágoras de Linhares, Linhares-ES. E-mail: leticiacau21@gmail.com \\ *Autor para correspondência
}

Artigo submetido em 30/07/2019, aceito em 31/10/2019 e publicado em 23/12/2019.

Resumo: A vegetação ciliar é essencial para qualidade e manutenção do curso hídrico, sendo considerada como Área de Preservação Permanente - APP conforme a Lei n ${ }^{\circ} 12651 / 12$, do Código Florestal. As matas ciliares, também especificadas por florestas ripárias, fornecem matéria orgânica e criam microhábitats dentro dos cursos d'água além de influenciarem na qualidade da água e proteção das margens reduzindo o assoreamento, protegem espécies da flora e fauna. Essas áreas, uma vez preservadas ou recuperadas, ao longo de todos os cursos d'água, são de grande importância, pois podem interligam fragmentos florestais ainda existentes. O Sítio Pampulha em Linhares/ ES, objeto deste estudo, possui uma barragem no curso hídrico e devido à ausência de vegetação e consequente comprometimento da preservação permanente em sua área, foi proposto para a propriedade a elaboração de um Plano de Recuperação de Áreas Degradadas (PRAD). O estudo visa apresentar diretrizes para elaboração de PRAD e restauração vegetal da área afetada, apresentando uma proposta metodológica de recuperação da área degradada considerando a descrição das fitofisionomias existentes no entorno das áreas de interesse bem como listar as espécies a serem utilizadas na recomposição da vegetação. Assim, com a implantação do PRAD e seu acompanhamento espera-se obter a restauração florestal do ambiente ciliar, proporcionando a recuperação do curso hídrico e sua manutenção, estabelecendo uma interligação da floresta existente com a nova vegetação.

Palavras-chave: vegetação ciliar; áreas degradadas; recuperação; PRAD.

Abstract: Riparian vegetation is essential for the quality and maintenance of the watercourse, being considered as Permanent Preservation Area - APP according to Law No. 12651/12 of the Forest Code. Ciliary forests, also specified by riparian forests, provide organic matter and create microhabitats within watercourses as well as influencing water quality and protecting banks by reducing siltation, protecting species of flora and fauna. These areas, once preserved or recovered, along all watercourses, are of great importance as they can interconnect existing forest fragments. The Pampulha Site in Linhares / ES, object of this study, has a dam in the water course and due to the absence of vegetation and consequent impairment of permanent preservation in its area, it was proposed for the property the elaboration of a Degraded Areas Recovery Plan (PRAD). The study aims to present guidelines for the elaboration of PRAD and plant restoration of the affected area, presenting a methodological proposal for degraded area recovery considering the description of the phytophysiognomies surrounding the areas of interest as well as listing the species to be used in the vegetation recomposition. Thus, with the implementation of the PRAD and its accompaniment it is expected to obtain the forest restoration of the riparian environment, providing the recovery of the 
water course and its maintenance, establishing an interconnection of the existing forest with the new vegetation.

Keywords: riparian vegetation; degraded areas; recovery; PRAD.

\section{INTRODUÇÃO}

A vegetação tem papel importante na estabilidade do solo. O manto florístico amortece o impacto das chuvas, regularizando e reduzindo o escoamento superficial e aumentando o tempo disponível para absorção da água pelo subsolo, contribuindo para evitar a instalação de processos de instabilidade (MARTINS, 2005).

A revegetação de áreas degradadas é importante para evitar o surgimento de processos erosivos, de instabilidade das barreiras, reduzir os assoreamentos das linhas de drenagem natural e evitar o aumento da turbidez e redução da qualidade das águas dos rios (COSMOS, 2009).

A obrigatoriedade de manutenção de matas ao redor de nascentes, rios ou reservatórios artificiais é prevista pela Lei $\mathrm{n}^{\mathrm{o}}$ 12651/12, do Código Florestal, que estabelece normas gerais sobre a proteção da vegetação, Reserva Legal e Áreas de Preservação Permanente (APP), esta última objeto deste estudo, classificada como área protegida, coberta ou não por vegetação nativa, com a função ambiental de preservar os recursos hídricos, a vegetação, a biodiversidade e proteção do solo, neste caso delimitada ao entorno dos reservatórios d'água artificiais, decorrentes de barramento ou represamento de cursos d'água naturais (BRASIL, 2012).

A propriedade apresentada neste estudo possui uma barragem no curso hídrico e devido à ausência de vegetação e consequente comprometimento da preservação permanente em sua área, foi proposto a elaboração de um Plano de Recuperação de Áreas Degradadas (PRAD). Este plano é um importante instrumento de gestão ambiental para outros tipos de atividades antrópicas, sobretudo aquelas que envolvem desmatamentos, terraplenagem, entre outros. Para qualquer dessas atividades a elaboração do PRAD é voltada para os aspectos do solo, vegetação e conservação do manancial.

Foi analisado e apontado a área a ser recuperada de acordo com a legislação, descrevendo as características locais de clima, relevo, pedologia, bacia hidrográfica e ecossistema e vegetação, foi feita a identificação e levantamento da fitofisionomia e espécies do local, a coleta de amostra de solo para por fim propor a implantação de uma estratégia de recuperação da área degradada, desenvolvendo técnicas de reflorestamento adequadas para o local.

A regularização da Área de Preservação Permanente (APP) próximo a reservatórios artificiais, atendendo a legislação vigente, busca a reintegração ambiental da área para assim, promover a manutenção da biodiversidade e qualidade do recurso hídrico, devido ao fato da água ser um recurso esgotável e sua fundamental proteção e conservação com a vegetação ciliar.

Este estudo visa apresentar diretrizes para elaboração de PRAD e restauração florestal da área afetada, apresentando uma proposta metodológica de recuperação da área degradada, considerando as fitofisionomias existentes no entorno da área de interesse bem como listar as espécies a serem utilizadas na recomposição da vegetação.

\section{REFERENCIAL TEÓRICO}

\subsection{A IMPORTÂNCIA DA VEGETAÇÃO CILIAR}

$\mathrm{Na}$ natureza, ao longo dos anos, a instalação de uma vegetação nas margens dos rios foi fundamental para a estabilização 
e existência dos leitos: as matas ciliares, assim denominadas pela similaridade da ação exercida pelos cílios na proteção dos olhos (PIOLLI et al, 2004).

A vegetação ciliar ocorre ao longo dos cursos d'água, incluindo tanto a ribanceira de um rio ou córrego, de um lago ou represa, banhados ou veredas, como também as superfícies de inundação e que sofrem influência do lençol freático.

Considera-se ainda a faixa de vegetação sob a interferência direta da presença de água em algum período do ano, que se apresentam em função disso sobre solo aluvional típico, com características florísticas e estruturais próprias, em que a vegetação do entorno também é florestal (MARTINS, 2005).

Atualmente, a restauração florestal em propriedades rurais tem se concentrado principalmente no ambiente ciliar (APP's), pois nas microbacias hidrográficas as matas ciliares desempenham importante papel ambiental ao proteger o sistema hídrico (CASTRO; MELLO; POESTER, 2012).

As matas ciliares, também especificadas por zonas ripárias, fornecem matéria orgânica para as teias alimentares dos rios, troncos e galhos que criam microhábitats dentro dos cursos d'água e protegem espécies da flora e fauna. Essas áreas, uma vez preservadas ou recuperadas, ao longo de todos os cursos d'água, são de grande importância pois podem interligar fragmentos florestais ainda existentes (ATTANASIO et al., 2006).

Segundo Castro, Mello e Poester (2012), as matas ciliares exercem importante função do ponto de vista hidrológico, ecológico e geomorfológico para a manutenção da saúde ambiental de uma microbacia hidrográfica. Do ponto de vista hidrológico, influenciam na qualidade e quantidade da água, na regulação do regime hídrico, na estabilização de margens do rio e na redução do assoreamento da calha do rio. Do ponto de vista ecológico exercem o papel de corredores ecológicos, interligando os fragmentos florestais na região, para que ocorra facilitação no trajeto de diversas espécies de animais, pólens e sementes, favorecendo o crescimento das populações de espécies nativas, as trocas gênicas e, consequentemente, a reprodução e a sobrevivência dessas espécies. E do ponto de vista geomorfológico a vegetação ciliar contribui para elevadas infiltrações e armazenamento temporário da água no solo e no subsolo, controla a erosão, conservando a qualidade dos solos, atuam como um filtro natural para eventuais resíduos de produtos químicos, fertilizantes e agrotóxicos e evitam o lixiviamento de substâncias essenciais para a manutenção do solo, controlando assim o assoreamento dos rios (PIOLLI et al., 2004).

Na propriedade objeto deste estudo, a recuperação da vegetação ao entorno do reservatório de água será de fundamental importância para conservação da qualidade e quantidade da água, para reestruturação do solo e contenção de erosão, e para interligação florestal com a vegetação existente no entorno da área de interesse.

\subsection{LEGISLAÇÃO AMBIENTAL E CÓDIGO FLORESTAL}

De acordo com o Código Florestal Brasileiro, Lei ${ }^{\circ} 12.651$, de 25 de maio de 2012, as matas ciliares são Áreas de Preservação Permanente (APP), sendo definidas como toda área, revestida ou não com cobertura vegetal, com a função ambiental de preservar os recursos hídricos, a paisagem, a estabilidade geológica, a biodiversidade, o fluxo gênico de fauna e flora, de proteger o solo e de assegurar o bem-estar das populações humanas.

De acordo com o artigo $4^{\circ}$ desta lei, em relação à delimitação de áreas de preservação permanente área em questão é incluída em reservatórios artificiais, dispostos no inciso III - as áreas no entorno dos reservatórios d'água artificiais, decorrentes de barramento ou represamento de cursos d'água naturais, na faixa definida na licença ambiental do empreendimento (BRASIL, 2012). 


\subsection{CRITÉRIOS NECESSÁRIOS PARA ELABORAÇÃO DE UM PLANO DE RECUPERAÇÃO DE ÁREAS DEGRADADAS (PRAD)}

Entende-se por área degradada a área que, por intervenção humana, apresenta alterações de suas propriedades físicas, químicas ou biológicas que possam comprometer, temporária ou definitivamente, a composição, estrutura e funcionamento do ecossistema natural do qual faz parte (MMA, 2013).

Recuperar uma área é tornar o ecossistema ali presente num estágio semelhante a sua condição original. Existem várias técnicas para recuperação de um ambiente, sendo a escolha dependente do estágio da degradação e das características de regeneração locais, devendo assim existir um PRAD específico para cada local (MMA, 2013).

O PRAD é um documento que orienta a execução e o acompanhamento ou monitoramento da recuperação ambiental de uma determinada área degradada. Neste documento devem contemplar a caracterização da área degradada e entorno, bem como do(s) agente(s) causador(es) da degradação; escolha de proposta de recuperação para a área degradada; definição dos parâmetros a serem recuperados com base numa área adotada como referência ou controle; adoção de um modelo de recuperação; detalhamento das técnicas e ações a serem adotadas para a recuperação; inclusão de proposta de monitoramento e avaliação da efetividade da recuperação; e previsão dos insumos, custos e cronograma referente à execução e consolidação da recuperação. Por fim, o documento deve ser elaborado por profissional habilitado acompanhado de Anotação de Responsabilidade Técnica (ART) (MMA, 2013).

\subsection{RECOMPOSIÇÃO DE MATAS} CILIARES, TÉCNICAS DE PLANTIO, ESPÉCIES E TRATOS CULTURAIS
Para a reposição das matas ciliares deve-se realizar um levantamento prévio das condições ambientais, mediante a caracterização dos fatores abióticos e bióticos do meio. A seleção do método a ser empregado dependerá do grau de degradação do meio, que pode ser avaliado pelo estado da vegetação (MARTINS, 2005).

Para a caracterização dos fatores bióticos, deve-se observar: a estrutura florística da área, identificação de adaptação das espécies ao encharcamento e identificação de plântulas ou mudas existentes. Uma vez definidos os fatores bióticos, pode-se partir para a recomposição da área, que pode consistir dos seguintes passos, definidos por Rodrigues e Gandolfi (1993 apud MARTINS, 2005):

i) escolha do sistema de reflorestamento;

ii) seleção das espécies a serem implantadas;

iii) definição das espécies em combinação dentro das unidades de plantio;

iv) distribuição das espécies no campo (definindo-se quantidade, forma e local); e

v) plantio e manutenção da área.

A recomposição das matas ciliares pode ser efetuada, basicamente por três métodos, considerando o local de sua implantação. A escolha da técnica a ser utilizada dependerá do grau de degradação das áreas, que pode ser avaliado por meio dos estudos florísticos e fitossociológicos, ou ainda pela avaliação fisionômica da vegetação ocorrente na área (MARTINS, 2005).

a) Implantações (ou plantio total) - em áreas bastante perturbadas que não conservam nenhuma das características bióticas das formações florestais ciliares originais daquela condição. Essa é uma situação típica de áreas cuja floresta original foi substituída por alguma atividade agropastoril (CADERNOS DA MATA CILIAR, 2009).

b) Enriquecimento - em áreas com estágio intermediário de perturbações 
que mantêm algumas das características bióticas e abióticas das formações ciliares típicas daquela condição, situação de áreas cuja floresta original foi degradada pela ação antrópica, ocupada por capoeiras, com domínio de espécies dos estágios iniciais de sucessão (CADERNOS DA MATA CILIAR, 2009).

c) Recuperação natural - nas áreas pouco perturbadas que retêm a maioria das características bióticas e abióticas das formações florestais típicas da região (CADERNOS DA MATA CILIAR, 2009).O isolamento deve ser um procedimento recomendado nesse tipo de recuperação, para que os processos naturais de sucessão possam atuar, impedindo o acesso de animais (equinos, bovinos e caprinos etc.) e limitando espacialmente a atividade agrícola, permitindo que os processos ecológicos se restabeleçam e que promovam a regeneração natural das espécies. Neste contexto, e considerando uma paisagem favorável, a próxima medida será remover os agentes degradantes e proteger as áreas para estimular a sucessão (MARTINS et al., 2014).

\subsubsection{Escolha das espécies}

A escolha das espécies é baseada em levantamentos florísticos de formações florestais ciliares originais remanescentes próximas à área em questão (ou mais distantes, mas com as mesmas características abióticas). A lista de plantas poderá ainda ser acrescida de espécies nativas frutíferas e melíferas não amostradas no levantamento, com o objetivo de fomentar a recuperação da fauna terrestre $e$ aquática, como também deverão ser priorizadas espécies zoocóricas (cujas sementes são dispersadas por animais) nativas da vegetação regional (CADERNOS DA MATA CILIAR, 2009).

É recomendado a utilização de espécies Pioneiras (espécies em início de sucessão, produzem grande número de sementes, ciclo de vida de 10 anos), Secundárias Iniciais (apresentam crescimento rápido e ciclo de vida entre 10 e 25 anos, regeneração por banco de plântulas) as duas são tolerantes a condições de maior luminosidade, Secundárias Tardias (Produzem frutos e sementes leves de pequenos a médios, tolerantes a sombra no estágio juvenil e tempo de crescimento médio e ciclo de vida longo de 25 a 100 anos, possuem regeneração por banco de plântulas efêmero) ou clímax (Germinação e desenvolvimento preferencialmente à sombra, tempo de crescimento lento ou muito lento e ciclo de vida muito longo, mais de 100 anos, com regeneração por banco de plântulas) (SMA/RJ, 2009; BARBOSA, 2006).

Desta forma, as espécies consideradas pioneiras são representadas pelas pioneiras iniciais e secundárias iniciais, nas classificações ecológicas, assim como as definitivas são representadas pelas secundárias tardias e clímax, de acordo com as classificações apresentadas anteriormente. A implantação é realizada de forma simultânea, com os dois grupos de espécies plantados de uma só vez (NOFFS; GALLI; GONÇALVES, 2000).

\subsubsection{Plantio}

De acordo com Martins (2005), o plantio de espécies deve ser por meio de coveamento, as covas devem possuir uma forma côncava para armazenar a água e umidade para sobrevivência das mudas que devem ser espécies adequadas e resistentes ao tipo de solo e clima da região.

O plantio deverá ser feito intercalando linhas de mudas Pioneiras (espaçamento de 3,0 x 3,0 metros) com linhas de mudas definitivas, utilizando o mesmo espaçamento. As covas devem ter dimensão de $30 \times 30 \times 30 \mathrm{~cm}$, e o plantio deve ser feito em nível, de forma que uma linha fique desencontrada da outra, formando um triângulo entre as plantas (CHAVES et al., 2012), tal como demonstrado na Figura 1. 
Figura 1: Ilustração de forma de plantio, sendo $\mathrm{a}$ e $\mathrm{b}$ as distâncias entre as fileiras e as plantas, respectivamente.

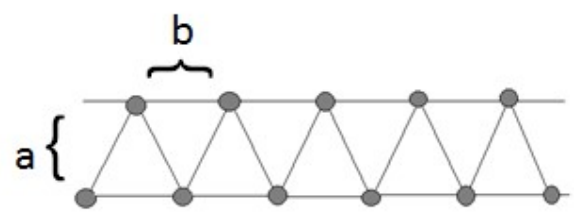

Fonte: Acervo técnico (2016).

\subsubsection{Abertura de Covas e Espaçamento}

Se a declividade do terreno permitir, pode-se efetuar o sulcamento mecânico na área ou mesmo a abertura manual das covas (ATTANASIO et al., 2006).

No coveamento deverão ser abertas covas de $0,30 \mathrm{~m} \times 0,30 \mathrm{~m} \times 0,30 \mathrm{~m}$, com espaçamento de 3 metros na linha $X 3$ metros na entre linha. Toda terra retirada deverá ser deixada do lado das covas para sofrer incorporação completa com fertilizantes (ATTANASIO et al., 2006).

\subsubsection{Adubação nas Covas}

A adubação é realizada de acordo com o resultado de análises do solo e conforme a necessidade, os nutrientes indicados foram inseridos e servirão para acelerar o desenvolvimento inicial das mudas e reduzir a competição com as plantas daninhas. As espécies pioneiras apresentam maior capacidade de absorção de nutrientes, assim o plantio deve receber adubação correta em quantidade e qualidade. $\mathrm{O}$ uso de fontes de corretivos e fertilizantes deverá suprir deficiências e sincronizar a velocidade de decomposição dos resíduos com as exigências de nutrientes das plantas cultivadas (NAPPO et al., 1999).

De modo geral, a correção do $\mathrm{pH}$ do solo deve ser feita mediante calagem mantendo seu valor por volta de 6,0 a 6,5 por ser a faixa ideal para o desenvolvimento da maioria das plantas. Quanto à fertilização, deve ser feita de forma a corrigir deficiências mais severas dos principais nutrientes (NAPPO et al.,1999).
É importante destacar que na aplicação de adubos, deve-se atentar para que não ocorra escorrimento superficial na área em questão, preferindo-se sempre a adubação na cova (NAPPO et al., 1999).

\subsubsection{Irrigação}

Normalmente, o plantio é efetuado na época das chuvas, quando o solo apresenta umidade suficiente para garantir a sobrevivência das mudas (MARTINS, 2005). Podem ser implantados sistemas de irrigação para auxiliar no desenvolvimento da vegetação, caso ocorra períodos de seca prolongada.

\subsubsection{Tratos Culturais}

Após um ano e meio decorridos da recomposição recomenda-se ser feitas capinas de limpeza na linha de plantio e o coroamento de espécies para evitar plantas gramíneas que podem prejudicar o crescimento das mudas. Deve-se utilizar um espaço curto na hora da plantação, pois diminui o espaço para plantas invasoras se instalarem (MARTINS, 2005).

Para retirar as ervas daninhas é indicado o trabalho manual (enxadas, foices ou outros recursos), pois o controle químico é restrito e pode ser prejudicial à bacia (NAPPO et al., 1999).

No preparo do solo para o plantio das mudas deverá ser feita a verificação da área, antes do plantio, a fim de verificar se existem olheiros de formigas cortadeiras, pois essa é considerada a principal praga de florestas plantadas. Caso exista deverá ser identificada quanto ao gênero (Atta $s p$ Saúva e Acromyrmexsp - Quem-quem), visando à escolha do melhor método para combatê-las.

Formigas cortadeiras e cupins podem interromper $\mathrm{o}$ processo de reflorestamento, causando até a morte de mudas. No entanto, as formigas em nível normal ajudam na dispersão de mudas e gramíneas e são importantes para proteção do solo contra erosão (NAPPO et al., 1999). 
Neste período também é importante fazer preparo das covas e o cercamento da área para mantê-la isolada dos animais (bovinos e equinos) (NAPPO et al., 1999).

\subsection{PRINCIPAIS CARACTERÍSTICAS DO MEIO FÍSICO CAPIXABA}

\subsubsection{Clima e Relevo}

O Espírito Santo está situado na região tropical, possuindo clima quente e chuvoso, sem a presença de uma estação fria definida. De acordo com a classificação de Koppen que leva em consideração os aspectos gerais do regime de chuvas e das temperaturas, o Estado pode ser classificado em seis tipos climáticos: Am - sem período de seca; Aw - com seca no inverno; $\mathrm{CFa}$ com verão quente sem estação seca; $\mathrm{CFb}$ Com verão brando e sem seca; Cwa - com verão quente e com seca no inverno; $\mathrm{CWb}-$ com verão brando e com seca no inverno (ANTONGIOVANNI e COELHO, 2005).

Esta diversidade climática é justificada pela posição geográfica (latitude) e pelas características de relevo. Quanto a posição geográfica o Estado está localizado em uma faixa intertropical do globo, marcado pelo encontro de massas de ar, influenciado pelo sistema Tropical Atlântico que predomina grande parte do ano, como também, do Sistema Equatorial Continental, ocasionando Linhas de Instabilidade a Tropical sobretudo no verão podendo provocar chuvas intensas e duradouras com cerca de $60 \%$ das chuvas anuais (ANTONGIOVANNI e COELHO, 2005).

Dessa forma, quase a totalidade do território capixaba apresenta-se temperaturas medias anuais elevadas durante boa parte do ano e, mesmo nos meses mais frios, as temperaturas medias são superiores a $18^{\circ} \mathrm{C}$ (ANTONGIOVANNI e COELHO, 2005).

As médias anuais são em torno de 20 ${ }^{\circ} \mathrm{C}$ e $25^{\circ} \mathrm{C}$ nas planícies litorâneas e em direção ao interior do Estado até a cota $500 \mathrm{~m}$, ocupando a maior parte da área do Estado, cerca de $80 \%$ e, grande parte de sua população. A exceção fica para a região
Serrana que, eventualmente, alcança esta temperatura. $\mathrm{O}$ valor mínimo médio dificilmente chega aos $15^{\circ} \mathrm{C}$ (ANTONGIOVANNI e COELHO, 2005).

$\mathrm{O}$ relevo do estado é caracterizado por baixada litorânea ( $40 \%$ do território) e serras (interior). O relevo é formado por rochas cristalinas, sobretudo gnaisses e granitos. Ao longo da costa Atlântica encontra-se uma faixa de planície e à medida que se penetra em direção ao interior, o planalto dá origem a uma região serrana, com altitudes superiores a 2.000 metros (ESPÍRITO SANTO, 2017).

De largura variável, a Baixada espírito-santense acompanha toda a costa capixaba, da fronteira com a Bahia até o limite com o Rio de Janeiro. O litoral é rochoso ao sul, com falésias de arenito, e também na parte central, com grandes morros e afloramentos graníticos a beira mar, além de ser recortado com enseadas e baias. É arenoso ao norte, com praias longas de mar aberto e cobertas por uma vegetação rasteira. Destaque para as dunas de Itaúnas, no extremo norte capixaba (ESPÍRITO SANTO, 2017).

\subsubsection{Ecossistema e Vegetação}

Do ponto de vista geológico, Amorim (1984 apud IPEMA, 2005) considera que o Espírito Santo pode ser dividido em duas zonas principais: zona dos tabuleiros e zona serrana, esta primeira será descrita pois está inserida no local de interesse deste trabalho.

A zona dos tabuleiros compreende o terraço litorâneo, plano ou levemente ondulado, de altitude média em torno de 50 m. No Espírito Santo ocupa uma faixa estreita ao sul, entre as planícies e as primeiras escarpas das serras interioranas. Ao norte de Vitória alarga-se, tornando-se expressiva entre Linhares e São Mateus e prolonga-se até o sul da Bahia. A floresta de tabuleiros caracteriza-se por uma vegetação densa, com exemplares de altura média acima de $30 \mathrm{~m}$. As árvores são espaçadas, o sub-bosque é pouco denso e apresentam-se 
poucas epífitas. Destaca-se a semelhança fisionômica e florística desta floresta com a floresta amazônica (Amorim, 1984 apud IPEMA, 2005).

\section{$\mathrm{Na}$ Floresta Ombrófila Densa} apresentam-se árvores de grande porte nos terraços aluviais e nos tabuleiros terciários, enquanto nas encostas marítimas as árvores são de porte médio. Alguns gêneros são típicos e caracterizam bem esta região da encosta atlântica até o rio Doce, como Parkia e Attalea (IBGE, 1978).

Como objeto deste estudo, a região norte é caracterizada pela existência de Floresta Ombrófila Densa das Terras Baixas, situada entre os $4^{\circ}$ de latitude $\mathrm{N}$ e os $16^{\circ}$ latitude $\mathrm{S}$, a partir dos $5 \mathrm{~m}$ até os $100 \mathrm{~m}$ acima do mar; de $16^{\circ}$ de latitude $\mathrm{S}$ a $24^{\circ}$ de latitude $\mathrm{S}$ de $5 \mathrm{~m}$ até $50 \mathrm{~m}$; de $24^{\circ}$ de latitude $\mathrm{S}$ a $32^{\circ}$ de latitude $\mathrm{S}$ de $5 \mathrm{~m}$ até 30 m. É uma formação que em geral ocupa as planícies costeiras, capeadas por tabuleiros pliopleistocênicos do Grupo Barreiras (IPEMA, 2005).

\subsubsection{Hidrografia}

Em relação à bacias hidrográficas, o Estado do Espirito Santo possui a Bacia do Rio Doce, que é o mais importante do estado, com $853 \mathrm{~km}$ de extensão desde a nascente. Ele nasce no estado de Minas Gerais e desemboca no oceano Atlântico, na cidade de Linhares. Também se destacam os rios São Mateus, no norte do estado, o Itaúnas, o Itapemirim, o Jucu, o Santa Maria da Vitória, que desemboca na baía de Vitória e o Itabapoana, que separa o Espírito Santo do Rio de Janeiro (ESPÍRITO SANTO, 2017).

Até desaguar no Oceano Atlântico, perto da cidade de Nova Regência (ES), o rio Doce percorre uma distância de $853 \mathrm{Km}$, drenando uma bacia hidrográfica de 83.431 $\mathrm{Km}^{2}$ (SEAMA, 1980).

Possui também a Bacia do Rio Riacho, destacando-se com os rios: Rio Preto, Rio Santana, Rio S. Domingos, Córrego Dezoito, Córrego Claro, Ribeirão Suzano, Rio Rib. Dourado. A bacia hidrográfica em foco é constituída por um conjunto de sub-bacias independentes, dos quais se destacam a do rio Riacho e a do Perequê-Açú. Possui uma superfície de $1.660 \mathrm{Km}^{2}$, compreendendo terras dos municípios de Aracruz, Ibiraçu, João Neiva, Linhares e Santa Teresa. Tanto o rio do Riacho como o Pequerê-Açu são importantes mananciais que, além de suprir o complexo de produção de papel e celulose no município de Aracruz, abastecem com água potável os centros urbanos e distritos inseridos na bacia (SEAMA, 1980).

\section{Figura 2: Bacias Hidrográficas do ES.}

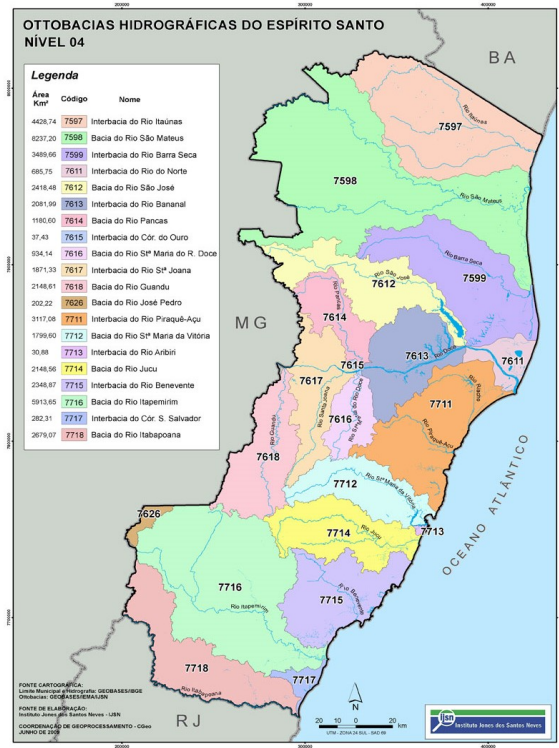

Fonte:IJSN (2009).

\subsubsection{Pedologia}

Os solos do Estado do Espírito Santo podem ser recentes e rasos ou profundos e intemperizados. Podem ser planos ou acidentados; escuros ou claros; ora avermelhados, ora mais amarelados (CUNHA et al., 2016).

As Rochas Cristalinas PréCambrianas são de aspecto gnáissico em sua quase totalidade e fazem parte do Escudo Cristalino Brasileiro, que se estende em continuidade aos Estados vizinhos de Minas Gerais e Rio de Janeiro. Caracterizam-se por evidenciarem fácies de metamorfismo de médio, e alto grau (PANOSO, 1978).

Do ponto de vista estrutural e 
textural, diversificações profundas e marcantes são observadas: regiões em que os tipos gnáissicos se apresentam bastante orientados, xistosos, com mergulhos proeminentes, em contraste com outra Zonas do Estado em que as rochas exibem um aspecto mais maciço, ou, como mais comum, ocorrem grupadas em zonas de granitizações progressivas (PANOSO, 1978).

O material originário compreende a fração do solo, acrescida de detrito orgânicos, cobre os quais atuaram es processos pedogenéticos de formação.

Verificou-se que a correlação das diversas unidades de solos com o material que lhes deu origem, se local ou transportado, pode ser melhor estabelecida no Espírito Santo, quando se tem por base o tipo de relevo sobre os quais eles se desenvolveram (PANOSO, 1978).Sendo assim, os principais tipos de solos podem ser classificados como:

\section{a) Latosolo Vermelho Amarelo}

São os solos de maior extensão em área, desenvolvidos principalmente sobre terrenos Pré-Cambrianos e Terciários e em menor escala nos terrenos do Terciário ao atual. Seu material de origem é proveniente de rochas geralmente ácidas para os solos que ocorrem nos terrenos cristalinos e de sedimentos deficientes em minerais primários e pesados, quando se situam em áreas sedimentares. São subdivididos em Latosolo de relevo montanhoso e forte ondulado; Latosolo Vermelho Amarelo Húmico; Latosolo de Relevo forte ondulado; Latosolo de relevo ondulado; Latosolo de relevo plano e suave ondulado (PANOSO, 1978).

\section{b) Latosol Vermelho Escuro}

Ocorrem em áreas restritas de relevos suave ondulado, plano e forte ondulado, desenvolvidos principalmente sobre sedimentos Terciários e Terciários ao atual e em menor proporção sobre depósitos argilo-arenosos assentes em substrato gnáissico (PANOSO, 1978).

c) Podzólico Vermelho Amarelo Estes solos não tão comuns quanto os Latossolos, mas de certa representatividades no Estado, ocorrem desenvolvidos sobre terrenos cristalinos Pré-Cambrianos e Sedimentos Terciários e Terciários ao atual.

O material de origem é proveniente de rochas intermediárias e ácidas para os Podzólicos desenvolvidos sobre terrenos cristalinos e de sedimentos deficientes em minerais primários e pesados quando ocorrem em terrenos Terciários e Terciários ao atual. Subdividem-se em Podzólico Vermelho Amarelo de relevo forte ondulado e montanhoso; Podzólico Vermelho Amarelo de relevo ondulado; Podzólico Vermelho Amarelo de relevo suave ondulado e Podzólico Vermelho Amarelo de relevo plano e suave ondulado (PANOSO, 1978).

\section{d) Solos Cambissólicos}

Ocorrem em regiões de relevo escarpado, montanhoso e forte ondulado, associados por vezes a afloramentos de rocha. Como nos demais solos de relevo montanhoso e forte ondulado do Estado, excetuando-se os Latossolos Húmicos, o material de origem é principalmente autóctone, acrescido de materiais de transporte local, em geral provenientes de rochas semelhantes às que ocorrem nos substratos dos solos em questão (PANOSO, 1978).

\section{e) Podzol Hidromórfico}

Estão situados sobre as restingas litorâneas, correspondendo a sedimentos arenosos depositados pelo mar ou que posteriormente se acumularam sob a forma de dunas pela ação do vento. O material de origem é portanto alóctone,: a reserva mineral é nula; e ao longo do perfil observam-se traços de alguns minerais pesados: turmalina, silimanita, ilmenita e granada (PANOSO, 1978).

\section{f) Solos Aluviais \\ Estes solos ocorrem sobre} sedimentos, aluviais, Quaternário recente, depositados nas planícies de inundação ou nos deltas dos cursos d'água a que estão associados, destacando-se pela área que ocupam; os solos Aluviais encontram-se ao 
longo dos rios Doce, São Mateus, Itapemirim, Jucu, Iriri-Mirim e Guandú (PANOSO, 1978).

\section{PROCESSOS METODOLÓGICOS: MATERIAIS E MÉTODOS \\ 3.1 QUANTO AO TIPO DE PESQUISA}

O presente trabalho trata-se de um estudo de caso de natureza qualitativa. De acordo com Ferrão (2005), "a metodologia qualitativa é caracterizada pelos seus atributos e relaciona aspectos não somente mensuráveis, mas também definidos descritivamente'.

Para o alcance dos objetivos a pesquisa será do tipo de campo/descritiva. Cruz e Ribeiro (2003), afirma que a pesquisa de campo "consiste na observação atenta de um objeto (ou fenômeno) de interesse do pesquisador [...]", e a pesquisa descritiva tem por objetivo principal "registrar, observar, analisar e correlacionar fatos u fenômenos (variáveis) sem manipulá-los [...]" (ACKOFF, 1975, p.172 apud. CASTRO, 2006).

E por fim do ponto de vista dos procedimentos técnicos caracteriza-se como estudo de caso onde permite o conhecimento amplo e detalhado ao explorar situações reais do local escolhido para o estudo (GIL, 2010).

\subsection{CARACTERIZAÇÃO DA ÁREA DE ESTUDO}

A propriedade escolhida para $o$ presente estudo foi o Sítio Pampulha, que está localizado no Córrego Alto distrito de Rio Quartel zona rural de Linhares no Espírito Santo, situada entre as coordenadas, em UTM, zona $24 \mathrm{~L}$ e meridiano central $39^{\circ}, \mathrm{X}=372761$ e $\mathrm{Y}=7.839 .957$.

A área total da propriedade é de 1.417.946,12 $\mathrm{m}^{2}$, aproximadamente 142 hectares, e a área proposta para o PRAD em APP, de acordo com a legislação municipal é de 47.220,70 $\mathrm{m}^{2}$, aproximadamente 4,72 hectares. Nela estão inseridos culturas perenes, como coco e café conilon, que necessitam de água para seu desenvolvimento, destacando a necessidade de recuperação da vegetação para manutenção e conservação do curso hídrico.

Para nortear a elaboração da proposta do PRAD, foi levada em consideração a Resolução CONSEMA n ${ }^{\circ}$ 003 de 06 de outubro de 2011, que institui diretrizes gerais para elaboração de Planos de Recuperação de Áreas Degradadas PRAD e estabelece procedimentos relacionados ao tema; e a Instrução Normativa do Instituto de Defesa Agropecuária e Florestal do Espírito Santo (IDAF) $n^{\circ} 008$ de 08 de agosto de 2014, que institui as normas e procedimentos que regulam, em todo território do Estado do Espírito Santo o licenciamento ambiental e o cadastro das barragens instituído pelo Decreto Estadual no $3623-\mathrm{R}$ de 04 de agosto de 2014.De acordo com o Artigo 11 desta lei, ficam instituídos, os parâmetros para o estabelecimento das faixas de área de preservação permanente em barragens licenciadas pelo IDAF.

$$
\begin{aligned}
& \text { I - } 5 \text { (cinco) metros: para barragens } \\
& \text { localizadas em imóveis rurais com área } \\
& \text { de até } 1 \text { (um) módulo fiscal; } \\
& \text { II - } 8 \text { (oito) metros: para barragens } \\
& \text { localizadas em imóveis rurais com área } \\
& \text { superior a } 1 \text { (um) módulo fiscal e de } \\
& \text { até } 2 \text { (dois) módulos fiscais; } \\
& \text { III - } 15 \text { (quinze) metros: para } \\
& \text { barragens localizadas em imóveis } \\
& \text { rurais com área superior a } 2 \text { (dois) e } \\
& \text { de até } 4 \text { (quatro) módulos fiscais; } \\
& \text { VI - } 30 \text { (trinta) metros: para barragens } \\
& \text { localizadas em imóveis rurais com área } \\
& \text { superior a } 4 \text { (quatro) módulos fiscais. } \\
& \text { Parágrafo único - A faixa de área de } \\
& \text { preservação permanente será } \\
& \text { considerada a partir do nível máximo } \\
& \text { maximorum (IDAF, 2014). }
\end{aligned}
$$

As leis ambientais surgem como tentativa de proteger os fragmentos florestais de áreas ainda preservadas. Porém, sem uma política de extensão rural florestal ou de acesso à informação e conhecimento por parte dos agricultores para estimular este tipo de uso da terra corretamente, as ameaças e os problemas 
irão continuar e, inclusive, agravar-se (FENDEL, 2007).

\subsection{TÉCNICAS DE IDENTIFICAÇÃO DE ESPÉCIES}

No presente estudo de caso, os instrumentos para coleta de dados foram visitas em campo, quando foram obtidos registros fotográficos da área atual e da área de floresta remanescente próxima, bem como análise, através de conveniência e consulta à bibliografia, da fitofisionomia existente no entorno da área de interesse onde foram listadas as espécies relevantes, para assim selecionar as espécies a serem utilizadas na recomposição da vegetação.

Através da identificação das espécies em campo, juntamente com um profissional habilitado, o reconhecimento se deu sob observação e apontamento das espécies, onde foi consultada bibliografia de FRIGIERI et al., 2016; o Guia ilustrado para identificação das plantas da Mata Atlântica - FLORES et al., 2015 bem como o Manual de Identificação de mudas e espécies do Rio de Janeiro, 2009 para análise e comparação de folhagens, tronco,folhas e frutos, bem como tamanho da copa, altura e diâmetro do tronco, assim foram listadas no Quadro 1 algumas espécies nativas e exóticas encontradas no local.

\subsection{TÉCNICA DE COLETA DE SOLO, ANÁLISE E INTERPRETAÇÃO}

A fim de verificar a real condição desse solo, em março de 2016 foi realizada uma coleta de amostragem para análise agronômica e ambiental em laboratório. A interpretação foi feita utilizando uma tabela para parâmetros de base. Por meio dessa análise será possível a correta utilização de adubos no plantio e tratamento do solo.

Os locais para obtenção das amostras de solo nas glebas homogêneas não superiores a 10 hectares são determinados aleatoriamente em um caminhamento em ziguezague (IAPAR, 1996).
Com o auxílio de uma sonda, foram coletadas amostras simples em número de 10 a 20 pontos com profundidade entre $10 \mathrm{e}$ 30 metros, limpando-se em cada local a superfície do terreno, retirando-se as folhagens e outros restos de plantas, resíduos orgânicos, sem, contudo, raspar a terra. Foi evitado pontos em locais erodidos, ou onde havia solo modificado por formigas ou cupins, bem como utilizado como depósito de corretivos, adubos, estéreos, passagem de máquinas, animais entre outros.

As amostras simples foram reunidas em um balde plástico limpo e bem misturadas, formando uma amostra composta. Após homogeneização, foi retirado aproximadamente $500 \mathrm{~g}$ de terra, transferido para saco plástico sem uso, identificado pelo número correspondente da área e encaminhado ao laboratório de análises.

\section{RESULTADOS E DISCUSSÃO \\ 4.1 CARACTERÍSTICAS FÍSICAS DA ÁREA DE ESTUDO}

Foi realizado um levantamento topográfico com elaboração de croqui da propriedade em campo (Figura 3), demarcando o barramento e as margens do reservatório de água artificial, em seu período máximo de acumulação. Neste caso, conforme a legislação vigente, de acordo com o IDAF, através da Instrução Normativa $\mathrm{n}^{\circ} 08$ de 2014, foi demarcado uma extensão de 30 metros de vegetação de APP.

Foi constatado a inexistência de vegetação ciliar, a área estava encoberta por pastagens, e o reservatório estava vazio, daí a necessidade e importância de recuperação e plantio de espécies nativas para reestabelecer a biodiversidade local.

De acordo com o Código Florestal, Art. 12. Todo imóvel rural deve manter área com cobertura de vegetação nativa, a título de Reserva Legal, sem prejuízo da aplicação das normas sobre as Áreas de Preservação Permanente, observados os 
seguintes percentuais mínimos em relação à área do imóvel, excetuados os casos previstos no art. 68 desta Lei:

II - localizado nas demais regiões do País: 20\% (vinte por cento).

No ano de 2016 foi elaborado o Cadastro Ambiental Rural (CAR) da propriedade e protocolado no IDAF, é sabido que a propriedade não possui a percentagem de reserva recomendada no código florestal, que seria um total de 28,4 hectares de reserva legal, com a inclusão do plantio em área de preservação permanente, a propriedade ainda estará com débito de 16,31 hectares de vegetação nativa, que serão adquiridos na forma de compensação, de acordo com o artigo 66 do Código Florestal, ou seja, haverá aquisição da área equivalente em outro imóvel rural.

\subsubsection{Clima e Relevo}

O clima do município de Linhares, segundo a classificação de Koppen-Geiger é Af, sendo um clima do tipo tropical quente úmido com chuvas no verão e inverno seco. $\mathrm{O}$ índice pluviométrico de $1.193 \mathrm{~mm} / \mathrm{ano}$ e a temperatura média é de $23,4^{\circ} \mathrm{C}$, sendo a máxima de $32^{\circ} \mathrm{C}$ e a mínima de $19,6^{\circ} \mathrm{C}$. Em relação ao relevo, $85,8 \%$ do município possui relevo plano e $14,2 \%$ acidentado (INCAPER, 2013).

\subsubsection{Ecossistema e Vegetação}

A região de Linhares é composta pelo ecossistema de Floresta Tropical Atlântica (Mata Atlântica) e a fitofisionomia da região é predominantemente Floresta Ombrófila Densa, esta floresta recobre uma área de 3.124.300 ha ou 68,5\% do território do Estado. Ocorre sob um clima ombrófilo e dependente de chuva, sem período biologicamente seco durante o ano excepcionalmente com 2 meses de umidade escassa, com grande umidade concentrada nos ambientes dissecados das serras. As temperaturas médias oscilam entre 22 e $25^{\circ} \mathrm{C}$. Caracteriza-se por solos de baixa fertilidade, ora álicos ou distróficos (IBGE,1987 apud IPEMA, 2005).

\subsubsection{Bacia Hidrográfica}

A bacia hidrográfica da área em que o PRAD está inserido é a Bacia do Rio Riacho e o curso d'água que ocorre na região é um afluente do Córrego Quartel (GEOBASES, 2018).

\subsubsection{Pedologia}

Os tipos de solo encontrados em Linhares, na planície costeira são do tipo: arenoquartzosos profundos, aluviais eutróficos e distróficos na área de influência do rio Doce, com predominância para o primeiro, hidromórficos e podzol (PANOSO, 1978). A área em que o PRAD está inserido possui o solo do tipo Latossolo Vermelho Amarelo Distrófico, com Baixa CTC, Horizonte A moderada e Textura Argilosa (EMBRAPA, 2016).

\subsection{ESPÉCIES ENCONTRADAS NA VEGETAÇÃO}

A cobertura vegetal predominante do local de implantação do PRAD é formada principalmente por vegetação do tipo braquiária, portanto a área não se encontra em processos erosivos pois há presença de gramíneas para cobertura do solo e não há inclinação no terreno.

A vegetação existente numa área de APP próxima ao local de implantação do PRAD é composta por espécies do bioma Mata Atlântica listados no quadro 1, um pequeno aglomerado de árvores e arbustos, dentre eles, encontrando-se em maiores quantidades, estão as Leucenas (Figura 4). Também é observada a formação de "capoeiras", com a presença de gramíneas, arbustos e algumas árvores de grande porte isoladas. 
Figura 3: Área total da propriedade Sítio Pampulha em Linhares, ES e demarcação aproximada da área proposta para recuperação (marrom).
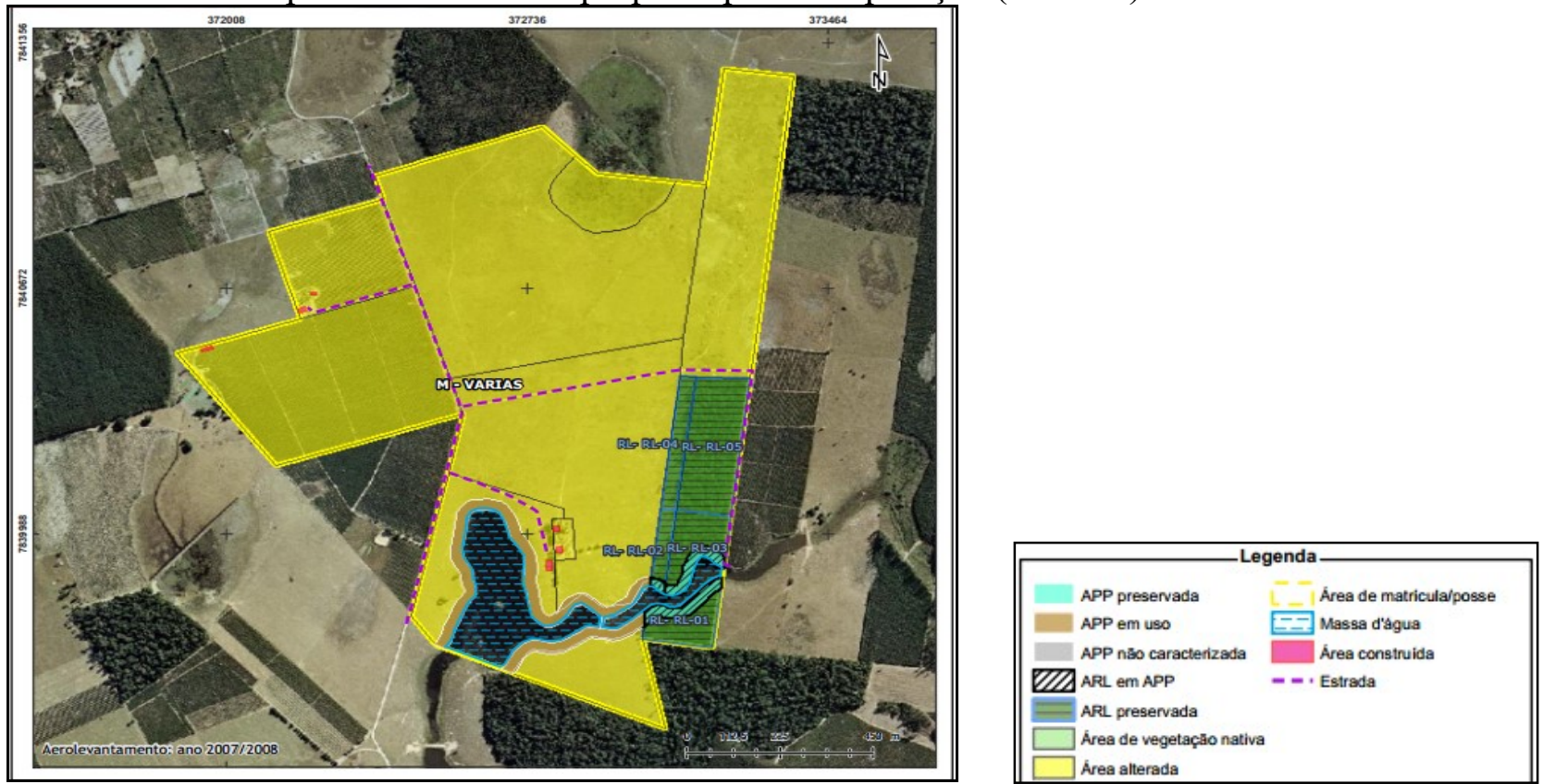

Fonte: Acervo técnico (2017).

As leucenas são espécies colonizadoras, produzem sementes de fácil disseminação e podem suprimir o desenvolvimento das espécies nativas, podendo acarretar perda da biodiversidade local, assim é pertinente realizar um controle na área de implantação para que não ocorra a proliferação dessa espécie (XAVIER e MORENO, 2008).

Em áreas de proteção ambiental, como áreas de preservação permanente, o desenvolvimento de espécies invasoras muitas vezes ameaça de forma significativa a função principal da floresta. Espécies como a leucena inibem o crescimento de espécies nativas, sendo extremamente eficazes quanto à capacidade de propagação de indivíduos e ainda ameaçam de forma direta a composição da fauna dessas áreas (CBD, 2005 apud SILVA et al, 2018).

A propriedade também possui em seus entornos áreas de plantio de cultura de café, áreas com plantio de coco além do reservatório de água proveniente da barragem (atualmente seco) (Figura 5). 
Figura 4: Leucenas em grande concentração, presentes na área de floresta remanescente próxima ao Sítio Pampulha em Linhares, ES.

Fonte: Acervo técnico (2017).

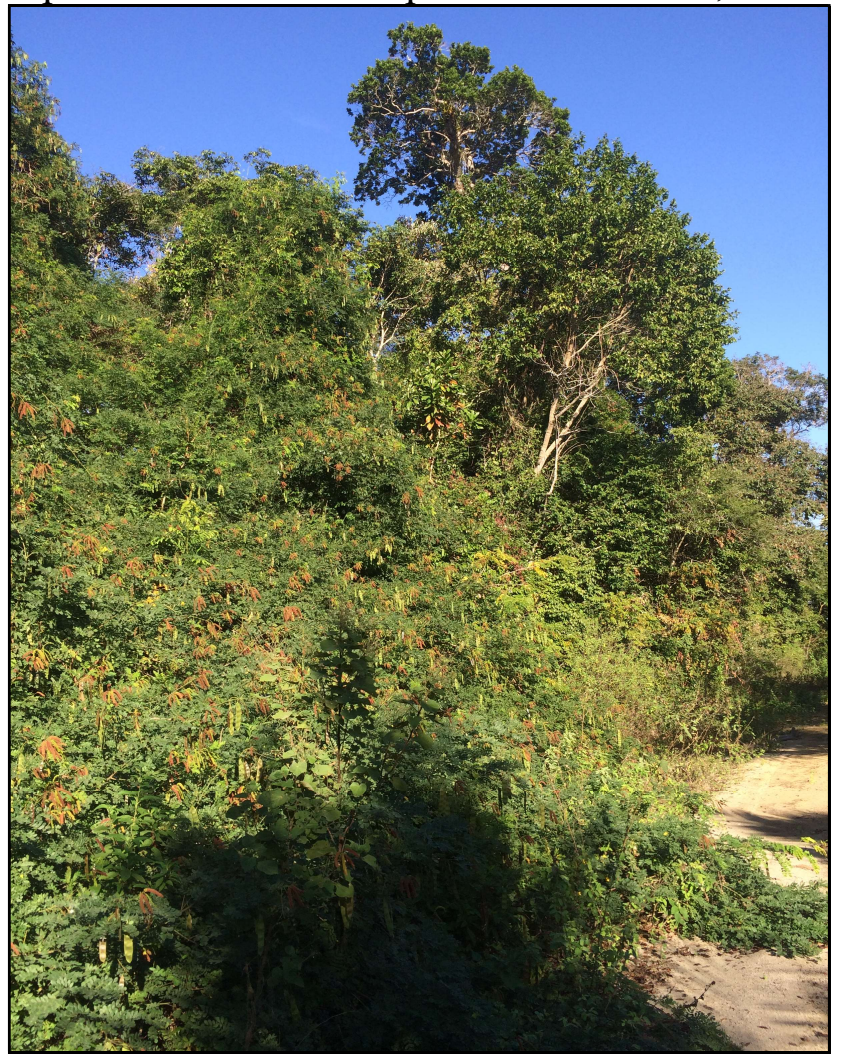

Figura 5: Área onde será inserido o PRAD no Sítio Pampulha em Linhares, ES

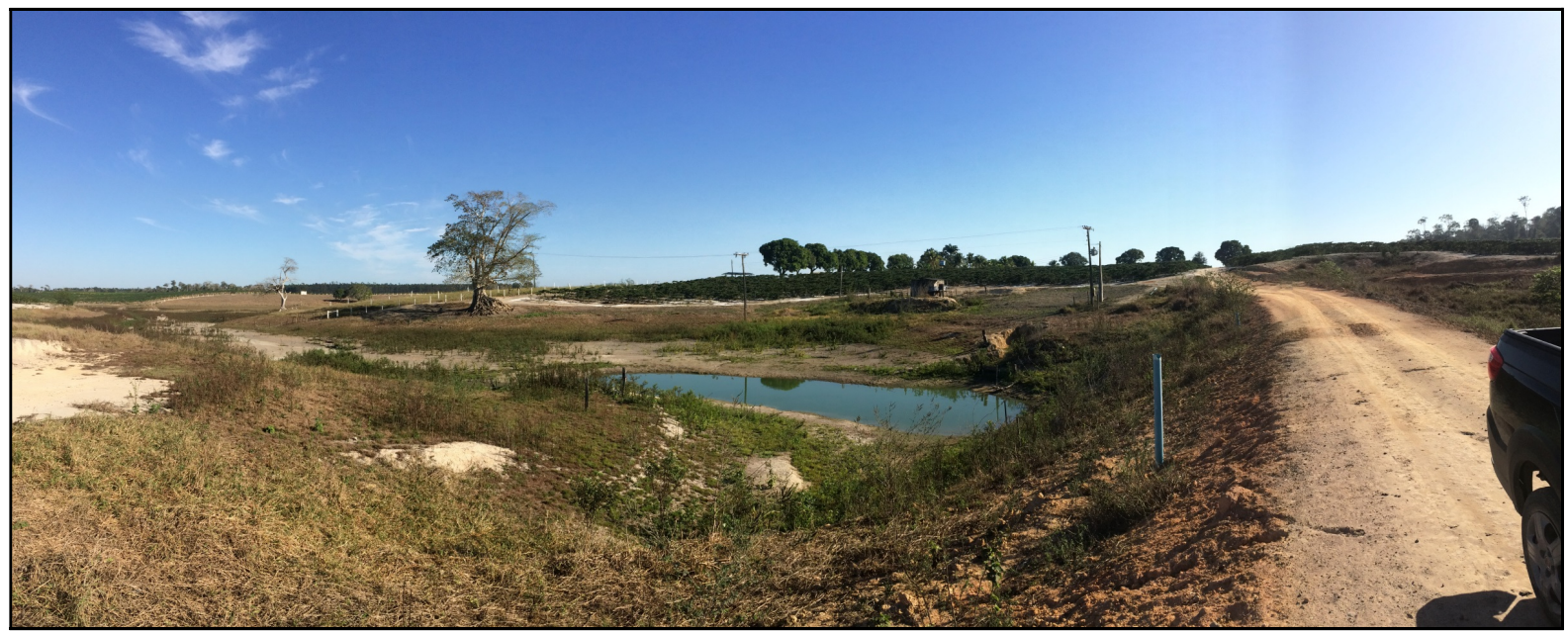

Fonte: Acervo técnico (2017). 
Quadro 1: Relação de espécies encontradas na área remanescente próxima ao local de implantação do PRAD no Sítio Pampulha em Linhares, ES.

\begin{tabular}{|c|c|c|c|}
\hline NOME CIENTÍFICO & NOME POPULAR & FAMÍLIA & ORIGEM \\
\hline Leucaena leucocephala & Leucena & Fabaceae & Exótica \\
\hline Eugenia stipitata & Araçá-boi & Myrtaceae & Nativa \\
\hline Albiziapoly polycephala & Farinha-Seca & $\begin{array}{l}\text { Leguminosae } \\
\text { Mimosoideae }\end{array}$ & Nativa \\
\hline Goniohachis marginata & Guarabu Amarelo & Fabaceae & Nativa \\
\hline Cariniana legalis & Jequitibá Vermelho & Lecythidaceae & Nativa \\
\hline Cariniana estrellensis & Jequitiba Branco & Lecythidaceae & Nativa \\
\hline Myracrodruon urundeuva & Gibatão & Anacardiaceae & Nativa \\
\hline Heliocarpus americanos & Algodoreira & Tiliaceae & Nativa \\
\hline Manilkara longifólia & Paraju & Sapotaceae & Nativa \\
\hline Hymenaea courbaril L. & Jatobá Preto & Fabaceae & Nativa \\
\hline Hymenaea parviflora & Jatobá Vermelho & Fabaceae & Nativa \\
\hline Copaifera langsdorffii & $\begin{array}{c}\text { Copaíba, Óleo Copaíba, } \\
\text { Pau D'óleo }\end{array}$ & $\begin{array}{c}\text { Leguminosae } \\
\text { Caesalpinioideae }\end{array}$ & Nativa \\
\hline Machaerium tristes & Pau Sangue & $\begin{array}{c}\text { Leguminosae } \\
\text { Papilionoideae }\end{array}$ & Nativa \\
\hline Lecythis pisonis & Sapucaia & Lecythidaceae & Nativa \\
\hline Xylosma ciliatifolia & $\begin{array}{l}\text { Pau-Espinho, Espinho- } \\
\text { Bravo Ou Sucará }\end{array}$ & Salicaceae & Nativa \\
\hline Ocotea odorífera & Canela Cheirosa & Lauraceae & Nativa \\
\hline Talisia intermedia Radlk. & Pitomba Amarela & Sapindacea & Nativa \\
\hline Tabebuia serratifolia & Ipê Amarelo & Bignoniaceae & Nativa \\
\hline Tabebuia heptaphylla & Ipê Roxo & Bignoniaceae & Nativa \\
\hline $\begin{array}{c}\text { Tynanthus elegans } \\
\text { Miers. }\end{array}$ & Cipó Cravo & Bignoniaceae & Nativa \\
\hline Lantana câmara & Camará & Verbenaceae & Nativa \\
\hline
\end{tabular}

Fonte: Acervo Técnico (2017).

\subsection{TÉCNICAS DE RECUPERAÇÃO}

A técnica de restauração de vegetação ciliar utilizada será a técnica de implantação, recomendada em locais degradados, que não possuem a conservação das características bióticas da vegetação ciliar. O plantio deve ocorrer conforme a sequência: pioneiras, secundárias iniciais, secundárias tardias e clímax. Tendo a seleção de mudas, sementes e espécies, com a função de acelerar o processo de sucessão natural (MARTINS, 2005). 
A Recuperação de mata ciliar da propriedade em questão será feita de acordo com a Resolução CONAMA n ${ }^{\circ} 429$, de 28 de fevereiro de 2011 e dar-se-á por meio de plantio de espécies nativas, onde:

$\S 5^{\circ}$ Será admitido, como prática de
apoio à recuperação, o plantio
consorciado de espécies nativas
perenes produtoras de frutos,
sementes, castanhas e outros produtos
vegetais, sendo permitida sua
utilização para extração sustentável
não madeireira.

BOTELHO et al. (1995) comentam que o sucesso de um projeto de implantação ou recomposição de matas ciliares depende principalmente de uma avaliação detalhada das condições do local de implantação, da seleção das espécies corretas, do modelo de plantio e em grande parte, das práticas de manejo adotadas no plantio e na condução da floresta.

Desta maneira foram selecionadas espécies para plantio na área a ser recuperada, com os devidos cuidados de selecionar espécies tolerantes a solos com elevado grau de umidade (próximos de cursos d'água) e espécies tolerantes a solos mais drenados (com possível déficit hídrico).

\subsubsection{Recuperação do Solo e Adubação}

Com o resultado da análise de solo, foi realizada a recomendação de adubação para o plantio das mudas de espécies nativas adquiridas.

Para iniciar o plantio de mudas é necessário realizar a adubação na cova, de acordo com Prezotti el tal, 2007 é recomendado adicionar 6 Litros de esterco bovino por cova.

Após 30 dias de plantio, deve-se realizar a adubação de cobertura, seguindo os parâmetros de fósforo e potássio obtidos no resultado da análise.

Considerando solos de Textura Média o Fósforo apresentou o teor de concentração média no solo e o potássio apresentou teor baixo, assim a adubação mineral de acordo com Prezotti el tal, 2007 deve seguir a tabela abaixo:

Tabela 1: Recomendação de Adubação de acordo com teor de Fósforo e Potássio

\begin{tabular}{|c|c|c|c|}
\hline \multirow{2}{*}{ Fósforo } & \multicolumn{3}{|c|}{ Potássio } \\
\hline & Baixo & Médio & Alto \\
\hline & \multicolumn{3}{|c|}{ 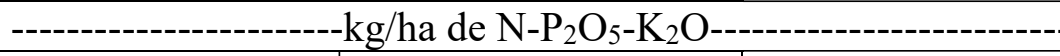 } \\
\hline Baixo & $20-40-30$ & $20-40-20$ & $30-40-0$ \\
\hline Médio & $20-25-30$ & $20-25-20$ & $30-25-0$ \\
\hline Alto & $20-0-30$ & $20-0-20$ & $30-0-0$ \\
\hline
\end{tabular}

Fonte: Prezotti et al (2007).

Portanto, com o teor de fósforo médio e o teor de potássio baixo, a disposição de adubação com NPK deverá ser numa proporção de $20-25-30 \mathrm{~kg} / \mathrm{ha}$.
Os parâmetros de micronutrientes encontram-se em níveis adequados para o desenvolvimento da essência nativa.

Tabela 2: Resultado da análise química de solos do Sítio Pampulha em Linhares, ES.

\begin{tabular}{c|c|c}
\hline PARÂMETRO ANALISADO & UNIDADE & $\begin{array}{c}\text { RESULTADO DA ANÁLISE } \\
\text { Área Limpa }\end{array}$ \\
\hline Fósforo-Mehlich & $\mathrm{mg} / \mathrm{dm}^{3}$ & 13 \\
\hline Potássio & $\mathrm{mg} / \mathrm{dm}^{3}$ & 34 \\
\hline Enxofre & $\mathrm{mg} / \mathrm{dm}^{3}$ & 18 \\
\hline Cálcio & $\mathrm{Cmol} / \mathrm{dm}^{3}$ & 3,0 \\
\hline
\end{tabular}




\begin{tabular}{|c|c|c|}
\hline Magnésio & $\mathrm{Cmol} / \mathrm{dm}^{3}$ & 0,4 \\
\hline Alumínio & $\mathrm{Cmol} / \mathrm{dm}^{3}$ & 0,0 \\
\hline $\mathrm{H}+\mathrm{Al}$ & $\mathrm{Cmol} / \mathrm{dm}^{3}$ & 3,4 \\
\hline pH em água & - & 5,7 \\
\hline Matéria Orgânica & $\mathrm{dag} / \mathrm{dm}^{3}$ & 2,6 \\
\hline Ferro & $\mathrm{mg} / \mathrm{dm}^{3}$ & 55 \\
\hline Zinco & $\mathrm{mg} / \mathrm{dm}^{3}$ & 10 \\
\hline Cobre & $\mathrm{mg} / \mathrm{dm}^{3}$ & 1,3 \\
\hline Manganês & $\mathrm{mg} / \mathrm{dm}^{3}$ & 29 \\
\hline Boro & $\mathrm{mg} / \mathrm{dm}^{3}$ & 0,91 \\
\hline Sódio & $\mathrm{mg} / \mathrm{dm}^{3}$ & 25 \\
\hline Relação $\mathrm{Ca} / \mathrm{Mg}$ & - & 7,5 \\
\hline Relação Ca/K & - & 34,4 \\
\hline Relação $\mathrm{Mg} / \mathrm{K}$ & - & 4,6 \\
\hline Sat. De Ca na CTC (T) & $\%$ & 43,6 \\
\hline Sat. De Mg na CTC (T) & $\%$ & 5,8 \\
\hline Sat. De K na CTC (T) & $\%$ & 1,3 \\
\hline Índice saturação de $\mathrm{Na}$ & $\%$ & 1,6 \\
\hline CTC a pH 7,0 (T) & $\mathrm{Cmol} / \mathrm{dm}^{3}$ & 7,0 \\
\hline Saturação de Alumínio (m) & $\%$ & 0 \\
\hline Saturação de bases (V) & $\%$ & 51,4 \\
\hline
\end{tabular}

Métodos Analíticos Conforme EMBRAPA (1998), PROFERT MG (1997) e IAC (2201).

Fonte: Laboratório Fullin (2016).

\subsubsection{Recomendação de Espécies e Plantio}

O grupo de diversidade é composto por espécies que possuem comportamentos sucessionais diferentes (secundárias iniciais, tardias e clímax) garantindo o processo de sucessão florestal.

Foram inseridas algumas espécies pioneiras que fazem parte do grupo de preenchimento, as quais são compostas por espécies que a pleno sol apresentam, simultaneamente, rápido crescimento e produzem grande cobertura do solo.

Considerando que a área a ser recuperada corresponde a 4,722 ha ou $47.220 \mathrm{~m}^{2}$, e o espaçamento entre as mudas de $3,0 \times 3,0 \mathrm{~m}$ (cada indivíduo ocupará $9 \mathrm{~m}^{2}$ da área), foram então necessários cerca de
5.771 indivíduos, (já incluídos os 10\% para o replantio)

As espécies recomendadas para o ambiente devem possuir características típicas da vegetação existente, assim, no Quadro 2 foram listadas as espécies adquiridas para o plantio, na proporção de $50 \%$ de espécies pioneiras e $50 \%$ de espécies definitivas.

Foram evitadas mudas da mesma espécie em covas próximas, com o objetivo de proporcionar diversidade, para isso, ao efetuar o plantio, as mudas foram misturadas de acordo com o grupo Pioneiras (pioneiras típicas e secundárias iniciais) e definitivas (secundárias tardias e clímax) já nas próprias caixas de distribuição. 
A aquisição de mudas nativas foi realizada no mês de fevereiro de 2018. O plantio foi realizado em curva de nível, no período de março de 2018, neste período não havia índices pluviométricos consideráveis, assim, a irrigação foi feita manual, através de pipas e irrigação por aspersão instalada no local.

As espécies foram inseridas conforme o esquema abaixo, a distribuição em forma de " $x$ ".

Quadro 2: Espécies indicadas e adquiridas para o plantio na área do PRAD no Sítio Pampulha em Linhares, ES.

\begin{tabular}{|c|c|c|c|}
\hline FAMÍLIA & ESPÉCIE & NOME VULGAR & $\begin{array}{c}\text { Grupo } \\
\text { Ecológico }\end{array}$ \\
\hline Anacardiaceae & TapiriraguianensisAubl. & Cupuba & SI \\
\hline Anacardiaceae & Schinus terebinthifolius Raddi & Aroeira & PI \\
\hline Annonaceae & Xylopia sericea A. & Pimenteira & SI \\
\hline Apocynaceae & Himathanthus lanceifolius & Agoniada & $\mathrm{ST}$ \\
\hline Apocynaceae & Peschiera fuchsiaefolia & Leiteiro & PI \\
\hline Asteraceae & Gochnatia velutina & Camará & PI \\
\hline Bignoniaceae & Tabebuia cassinoides & Pau-tamanco & SI \\
\hline Bombacaceae & Pseudobombax grandiflorum & Embiruçu & PI \\
\hline Boraginaceae & Cordia sellowiana Cham. & Baba de boi & PI \\
\hline Cecropiaceae & Cecropia glaziovi & Embaúba vermelha & PI \\
\hline Cecropiaceae & Cecropia pachystachya & Embaúba & PI \\
\hline Euphorbiaceae & Croton floribundus & Capixingui & PI \\
\hline Euphorbiaceae & Sapium biglandulosum & Leitero & PI \\
\hline Salicaceae & Casearia sylvestris $\mathrm{Sw}$. & Cafezinho & PI \\
\hline Leguminosae & Anadenanthera colubrina & Angico-branco & SI \\
\hline Leguminosae & Anadenanthera macrocarpa & Angico-vermelho & SI \\
\hline Leguminosae & Andira legalis & Angelim-coco & SI \\
\hline Leguminosae & Apuleia leiocarpa & Garapa & $\mathrm{ST}$ \\
\hline Leguminosae & Bauhinia germinata & Pata-de-vaca & SI \\
\hline Leguminosae & Dalbergia nigra & Jacarandá da Bahia & SI \\
\hline Leguminosae & Inga fagifolia & Ingá & SI \\
\hline Leguminosae & Inga laurina & Ingá-branco & SI \\
\hline Leguminosae & Machaerium vestitum & Jacarandá-branco & SI \\
\hline Leguminosae & Anadenanthera macrocarpa & Angico-vermelho & SI \\
\hline Leguminosae & Piptadaenia gonoacantha & Pau-jacaré & SI \\
\hline $\begin{array}{c}\text { Fabaceae } \\
\text { Caesalpinioidae }\end{array}$ & Schizolobium parahyba & Guapuruvú & SI \\
\hline
\end{tabular}




\begin{tabular}{|cccc|}
\hline FAMíLIA & ESPÉCIE & NOME VULGAR & $\begin{array}{c}\text { Grupo } \\
\text { Ecológico }\end{array}$ \\
\hline Clusiaceae & Calophyllum brasiliense & Guanandi & PI \\
Moraceae & Ficus clusiifolia & Gameleira & ST \\
Myrtaceae & Eugenia rostrifolia & batinga roxa & SI \\
Nyctaginaceae & Guapira opposita & Flor-de-pérola & ST \\
Sapindaceae & Cupania tenuivalves & Camboatã & PI \\
Leguminosae & Albizia polycephala & Farinha-seca & SI \\
Cannabaceae & Trema micranta & Curindiba & PI \\
Verbenaceae & Aegiphila sellowiana & Mululo & PI \\
Fabaceae & Senna occidentalis & Manjeriroba & PI \\
Myrtaceae & Psidium cattleyanum & Araçá & ST \\
Leguminosae & Dalbergia nigra & Jacarandá-da-Bahia & ST \\
Bignoniaceae & Tabebuia serratifolia & Ipê-amarelo & ST \\
Leguminosae & Caesalpinea férrea & Pau-ferro & SI \\
Leguminosae & Centrolobium tomentosum & Araribá & SI \\
Phytolaccaceae & Gallesia integrifólia & Pau-d'alho & SI \\
Bignoniaceae & Tabebuia heptaphylla & Ipê-roxo & ST
\end{tabular}

$\mathrm{SI}=$ Secundária Inicial $; \mathrm{ST}=$ Secundária Tardia $; \mathrm{PI}=$ Pioneira Fonte: Acervo técnico (2017).

Figura 6: Esquema de distribuição de espécies para o plantio no Sítio Pampulha em Linhares, ES.

Fonte: Noffs, Galli e Gonçalves (2000).

$$
\begin{array}{llll}
\text { Esquema de plantio: } & & & \\
& \text { P } & \text { D } & \text { P } \\
& \text { D } & \text { P } & \text { D } \\
& \text { P } & \text { D } & \text { P } \\
\text { P = espécies pioneiras } & & & \\
& & & \\
& &
\end{array}
$$

Num período de 30 dias após a implantação foi avaliada a necessidade de eventuais correções como a irrigação, adubação suplementar, execução de drenagem pluvial ou de correção de processos erosivos.

Após 90 dias de plantio, foi realizado a avaliação de replantio e constatado a perda de um pequeno número de espécies, guardados os $10 \%$ do total de mudas utilizado no plantio, de acordo com aqueles grupos e o número de espécies, as espécies necessárias para o replantio foram selecionadas e inseridas novamente no local.

Tendo em vista que os locais a serem reabilitados apresentam solos pobres em nutrientes e consideráveis variações no regime de chuvas, o plantio de mudas de baixa qualidade fisiológica implica em gastos adicionais com o replantio. Assim, foram selecionadas mudas de alta qualidade e de maior porte, mesmo que produzidas com um custo maior, pois propiciaram maior grau de sucesso na reabilitação e com a redução de uma série de custos nas operações de manejo pós-plantio.

Foram tomados cuidados relativos à aclimatação, visando aumentar a rusticidade das mudas e contribuir para sua adaptação às condições ambientais mais adversas das áreas de plantio. Para tanto, é necessária a 
adaptação gradativa das mudas às condições mais próximas daquelas predominantes na área de plantio como, por exemplo, a baixa disponibilidade de água e a forte insolação.

Figura 7: Destaque das espécies implantadas (a) e plantio em curvas de nível (b) no Sítio Pampulha em Linhares, ES.
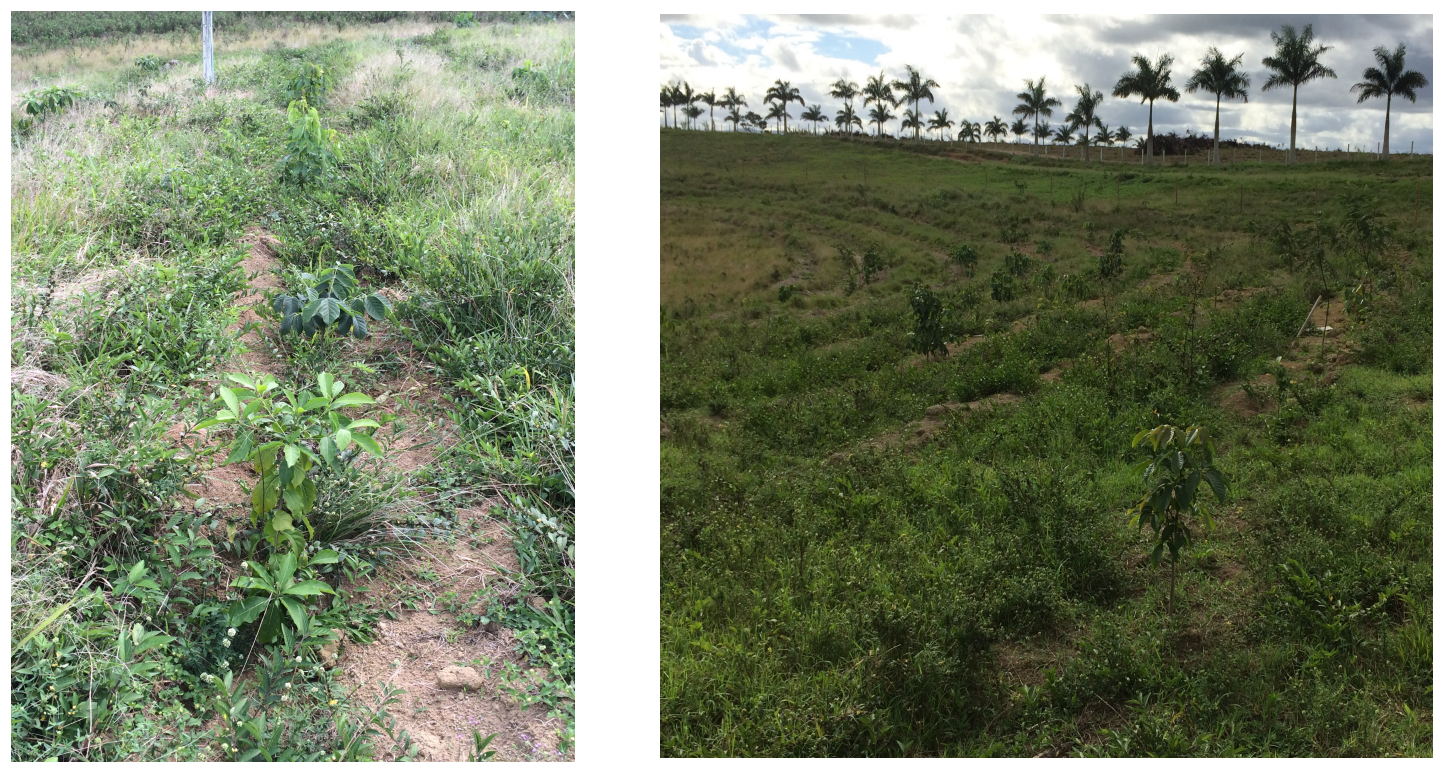

(b)

(a)

Fonte: Acervo técnico (2018).

Figura 8. Destaque do sistema de irrigação na área do PRAD do Sítio Pampulha em Linhares/ES.

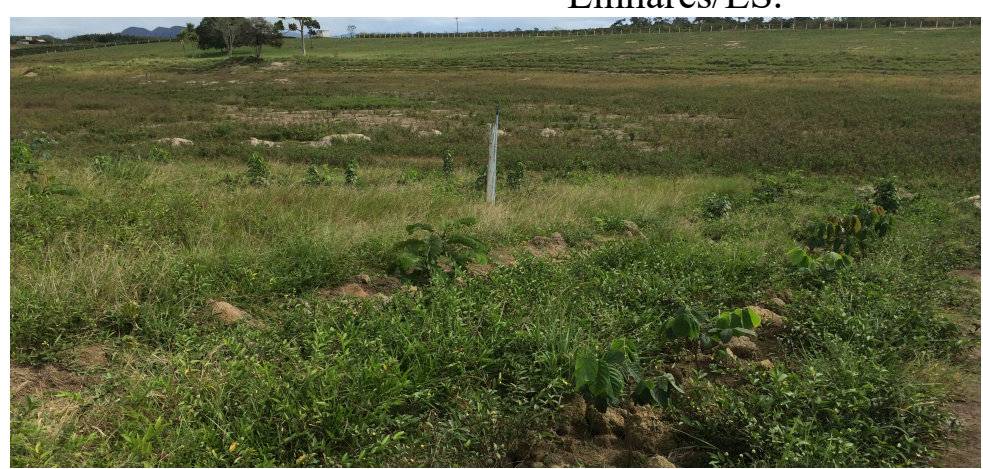

Fonte: Acervo técnico (2018). 


\section{CONCLUSÕES}

Embora a recuperação de uma área degradada seja um processo lento, o Projeto de Recuperação de Área Degradada (PRAD) tem apresentado um alto índice de sucesso com a utilização de espécies de rápido desenvolvimento. Espera-se que cerca de um a dois anos após o plantio, a área em questão se encontre em um estágio considerável de recuperação.

Recomendo a execução correta das técnicas utilizadas neste projeto, que possuem como benefícios ao meio ambiente a conservação dos recursos hídricos, a fixação e conservação da fauna e da flora, a contenção da erosão, além de minimizar ou eliminar os efeitos adversos decorrentes das intervenções e alterações ambientais, as quais são potencialmente geradoras de fenômenos indutores de impactos ambientais.

$\mathrm{Na}$ implantação do PRAD, foi mantido a vegetação gramínea existente para estabilização do solo e evitar processos erosivos, um fator importante para obtenção de resultados satisfatórios.

Assim sendo, com a implantação do PRAD e seu acompanhamento espera-se obter a restauração do ambiente ciliar, proporcionando a recuperação do curso hídrico e sua manutenção, estabelecendo uma interligação da floresta existente com a nova vegetação.

\section{AGRADECIMENTOS}

Gostaria de Agradecer as contribuições dos orientadores Msc. Vitor Pereira Mota, Esp. Hedeone Heidman da Silva e Dr. Ediu Carlos Lopes Lemos para a realização deste trabalho e aos proprietários do Sítio Pampulha, Sebastião Bergamaschi e Alair Bergamaschi pela confiança, implantação e execução do PRAD em sua propriedade.

\section{REFERÊNCIAS}

ANTONGIOVANNI, L.L.; COELHO, A.L.N. Panorama sobre a desertificação no estado do Espírito Santo. 2005.

ATTANASIO, C. M.; RODRIGUES, R.R.; GANDOLFI, S.; NAVE, A.G. Adequação ambiental de propriedades rurais: recuperação de áreas degradadas $e$ restauração de matas ciliares.

Universidade de São Paulo Escola Superior de Agricultura "Luiz de Queiroz", Departamento de Ciências Biológicas Laboratório de Ecologia e Restauração Florestal. Piracicaba - SP, 67p, 2006. BARBOSA, L, M. Manual Para Recuperação de Áreas Degradadas do Estado de São Paulo: Matas Ciliares do Interior Paulista. São Paulo: Instituto de Botânica, 129p, 2006.

BOTELHO, S. A.; DAVIDE, A.C.; PRADO, N.S.; FONSECA, E. M. B.

Implantação de mata ciliar. Companhia Energética de Minas Gerais - CEMIG, Belo Horizonte; Universidade Federal de Lavras - UFLA, Lavras, 28p. 1995.

BRASIL. Lei $\mathrm{n}^{\circ} 12.651$, de 25 de maio de 2012. Institui o novo Código Florestal. Brasília, 2012.

\section{CADERNOS DA MATA CILIAR /}

Secretaria de Estado do Meio Ambiente, Departamento de Proteção da Biodiversidade. - N 1 (2009) --São Paulo: SMA, 2009 N. 1 Reprodução de: Preservação e recuperação das nascentes de água e de vida / Redação Rinaldo de Oliveira Calheiros ...[et al.]. -- 2.ed. -- São Paulo: SMA, 2006. Disponível também: ISSN 1981-6235.

CASTRO, Claudio de Moura. A prática da pesquisa. 2 ed. São Paulo: Pearson Prentice Hall, 2006. 
CASTRO, D. de; MELLO, R. S. P.; POESTER, G. C. Práticas para

Restauração da Mata Ciliar. Porto Alegre: Catarse - Coletivo de Comunicação, 2012.

CHAVES, T. A.; ANDRADE, A. G.; LIMA, J. A. S.; PORTOCARRERO, H.

Recuperação de áreas degradadas por erosão no meio rural. Niterói - RJ: Programa Rio Rural, 2012.

CONAMA - Conselho Nacional do Meio Ambiente. Resolução n ${ }^{\circ} 429$, de 28 de fevereiro de 2011. Dispõe sobre a recuperação de Áreas de Preservação Permanente. Disponível em: <www.mma.gov.br/port/conama/res/res11/r es42911.pdf $>$. Acesso em: 18 de jan. 2017.

CONSEMA - Conselho Estadual do Meio Ambiente. Resolução do CONSEMA N ${ }^{\circ}$ 003/2011. Institui diretrizes gerais para elaboração de Planos de Recuperação de Áreas Degradadas - PRAD e estabelece procedimentos relacionados ao tema.

COSMOS, Engenharia e Planejamento. PRAD: Plano de Recuperação de Áreas Degradadas como Condicionante da Implantação do Hospital do Subúrbio Salvador, Bahia. 2009. Disponível em $<$ http://www1.saude.ba.gov.br/hospitaldosu burbio/docs/PRAD_COSMOS_FINAL_V1. pdf.> Acesso em: $0 \overline{2}$ ago. $201 \overline{6}$.

CRUZ, Carla; RIBEIRO, Uirá.

Metodologia científica. 5 ed. Rio de Janeiro, By: Cuccel Books do Brasil Ltda, 2003.

CUNHA, A. M.; FEITOZA, H. N.; FEITOZA, L. R.; OLIVEIRA, F. S.; LANI, J. L.; CARDOSO, J. H. K.; TRINDADE, F. $S$. Atualização da legenda do mapa de reconhecimento de solos do Estado do Espírito Santo e implementação de interface no Geobases para uso dos dados em SIG. GEOGRAFARES - Revista do Programa de Pós Graduação em Geografia e do Departamento de Geografia da UFES.
Julho - Dezembro, 2016. No 22 - Volume II. ISSN 2175 - 3709.

ESPÍRITO SANTO. Secretaria de Turismo. Descubra o Espírito Santo. ES, 2017.

Disponível em

$<$ http://descubraoespiritosanto.es.gov.br/pt/ o-espirito-santo>. Acesso: maio de 2018.

\section{FENDEL, K. L. Recuperação de Mata} Ciliar com Sistema Agroflorestal, Itajaí SC. Trabalho de Conclusão de Curso.

Universidade do Vale do Itajaí. Novembro 2007. Disponível em:

$<$ http://www.institutocarakura.org.br/arquiv osSGC/DOWN_201215TCC_agora_tmp4 97b62ca.pdf $>$. Acesso em: 29. jul.2016.

FERRÃO, Romário Gava. Metodologia científica. 2 ed. Espírito Santo: Incaper, 2005.

FLORES, T. B.; COLLETA, G. D.; SOUZA, V. C.; IVANAUSKAS, N. M.; TAMASHIRO, J. Y.; RODRIGUES, R. R. Guia ilustrado para identificação das plantas da Mata Atlântica: Legado das Águas Reserva Votorantim. São Paulo, Oficina de Textos, 2015. 225p.

FRIGIERI, F.F.; IWANICKI, N.S.; GANDARA, F.B.; FERRAZ, E.M.; ROMÃO, G.O.; COLETTI, G.F.; SOUZA, V.C.; MORENO, M.A. Guia de plântulas e sementes da Mata Atlântica do estado de São Paulo. Piracicaba: IPEF, 2016. 99p.

GEOBASES - Sistema Integrado de Bases Geoespaciais do Estado do Espírito Santo. 2013. Disponível em:< http://www.geobases.es.gov.br/portal/>. Acesso em: 22 out. 2016.

GIL, A. C. Como elaborar projetos de pesquisa. 5. ed. São Paulo: Atlas, 2010.

IAPAR - Instituto Agronômico do Paraná. Amostragem de Solo para Análise Química: plantio direto e convencional, culturas perenes, várzeas, pastagens $\mathrm{e}$ 
capineiras. Londrina, PR; 1996. 28p. ilust. (IAPAR. circular, 90).

IBGE - Instituto Brasileiro de Geografia e Estatística, 1978. Disponível em $<$ http://www.ibge.gov.br $>$ Acesso em: 01 ago. 2016.

IDAF - Instituto de Defesa Agropecuária e Florestal. Instrução Normativa $\mathrm{n}^{\mathrm{o}} 008$, de 08 de agosto de 2014. Instituir as normas e procedimentos que regulam, em todo território do Estado do Espírito Santo o licenciamento ambiental e o cadastro das barragens instituído pelo Decreto Estadual $\mathrm{n}^{\mathrm{o}} 3623-\mathrm{R}$ de 04 de agosto de 2014.

IJSN. Instituto Jones dos Santos Neves. Ottobacias Hidrográficas do Espírito Santo, 2009. Disponível em: < www.ijsn.es.gov.br $>$ Acesso em: 12 de julho de 2019.

INCAPER - Instituto Capixaba de Pesquisa, Assistência Técnica e Extensão Rural.

Programa de assistência técnica e extensão rural PROATER 2011-2013. Linhares, ES. 2013.

IPEMA - Instituto de Pesquisas da Mata Atlântica. 2005. Conservação da Mata Atlântica no Estado do Espírito Santo: cobertura florestal e unidades de conservação. Vitória - ES: IPEMA, 142p.

MARTINS, S.V. [et al]. Potencial de Regeneração Natural de Florestas Nativas nas Diferentes Regiões do Estado do Espírito Santo. CEDAGRO. Vitória, Espírito Santo, (Documento Técnico). 102p. 2014. Disponível em: $<$ http://www.cedagro.org.br/estudos/ESTU DO_REGENERACAO_NATURAL.PDF>

MARTINS, Sueli Sato. Recomposição de Matas Ciliares no Estado do Paraná. $2^{\text {a }}$ ed. Maringá - Paraná, 2005.

MMA. Roteiro de apresentação para plano de recuperação de área degradada (PRAD) terrestre. Parque Nacional da Serra da Bocaina. 2013. Disponível em: $<$ http://www.icmbio.gov.br/parnaserrad abocaina/images/stories/o_que_fazemos/ges tao_e_manejo/Roteiro_PRAD_versao_3.pdf >. Acesso em: 14 jul. 2019.

NAPPO, M. E., GOMES, L. J.; CHAVES, M. M. F. Reflorestamentos mistos com essências nativas para recomposição de matas ciliares. Boletim Agropecuário da Universidade Federal de Lavras, v.30, p.1 - 31, 1999.

NOFFS, P. da S.; GALLI, L. F.; GONÇALVES, J. C. Recuperação de áreas degradadas da Mata Atlântica: uma experiência da CESP (Companhia Energética de São Paulo). São Paulo: Conselho da Reserva da Biosfera da Mata Atlântica, 2000. Caderno n. 3.

PANOSO, Luzberto Acha. Levantamento de reconhecimento dos solos do estado do Espírito Santo. RJ: EMBRAPA, 461p. 1978

PIOLLI, A.L.; CELESTINI, R. M.; MAGON, R. Teoria e Prática em Recuperação de Áreas Degradadas: Plantando a semente de um mundo melhor. Secretaria de Meio Ambiente de São Paulo. FEHIDRO. Serra Negra, São Paulo. 2004.

PREZOTTI, L. C.; GOMES, J. A.; DADALTO; G. G; OLIVEIRA, J. A. de. Manual de recomendação de calagem e adubação para o Estado do Espírito Santo $-\mathbf{5}^{\mathrm{a}}$ aproximação. Vitória: SEEA/INCAPER/CEDAGRO, 2007. 305p.

PREZOTTI, Luiz Carlos; GUARÇONI M., André. Guia de interpretação de análise de solo e foliar. Vitória, ES: INCAPER, 2013. $104 \mathrm{p}$.

SEAMA, 1980, Mapa das Bacias

Hidrográficas do Espírito Santo. Vitória, ES. 
SILVA, O. M. C.; SANTANA, L. S.; XIMENES, L. M. A. S.; SANTANA, M, S. COMPORTAMENTO DA MADEIRA DE LEUCENA (Leucocena leucocephala Lam.) EM PROCESSOS DE USINAGEM.

Enciclopédia Biosfera. Centro Científico Conhecer - Goiânia, v.15 n.27; p.50. 2018. Disponível em

$<$ http://www.conhecer.org.br>. Acesso: 21 nov. 2019.

SMA/RJ - SECRETARIA MUNICIPAL
DE MEIO AMBIENTE. PREFEITURA DA CIDADE DO RIO DE JANEIRO. 2009. MANUAL DE IDENTIFICAÇÃO DE MUDAS DE ESPÉCIES FLORESTAIS. SEGUNDA EDIÇÃO.

XAVIER, T. M. T.; MORENO, M. R. Prejuízos causados pelas espécies exóticas invasoras na Floresta Nacional de Pacotuba. Universidade do Vale do Paraíba. p. 1-2. 200 